\title{
Equally Able, Differently Looking: Discrimination and Physical Violence against Persons with Albinism in Ghana
}

\author{
Francis Benyah \\ fbenyah87@gmail.com
}

\begin{abstract}
Albinism, an inherited condition from birth as a result of the lack of melanin pigment which usually changes the colour of the skin, hair and eyes, is usually greeted with resentment in most African communities. In Ghana, some communities and families consider it a misfortune to give birth to Albinos and hence, attempts are made to either kill them at birth or banish them from the community. They are constantly abused and ridiculed by the public with derogatory names and social tags that serve as a form of stigmatization. Evidently, it is clear that the discrimination against albinos in Ghana are underlain by religious and cultural beliefs. This article takes into perspective how religious beliefs and cultural values contribute to the plight of albinos in Ghana and further, discusses how the inculturation of human rights can help mitigate the violence that is perpetrated against persons with albinism.
\end{abstract}

Keywords: Albino, discrimination, human rights, violence, inculturation, cultural

\section{Introduction: Africans and an Enchanted Worldview}

Religion plays an essential role in various aspects of the Ghanaian society and culture. Ghana, just like many other African countries south of the Sahara, has a lot of religious beliefs and practices. In traditional African religion, the 


\section{Francis Benyah}

universe has been described as one "full of spirits" ${ }^{1}$ and religion is very largely the means through which these 'spirits' or forces are manipulated either for good or evil (Gifford 2015:13; Kalu 2010; Meyer 1999; Gyekye 1995). As Abamfo Ofori Atiemo (2013:21) argues, 'central to religion in Ghana is the concern to relate properly to a spiritual universe, which is thought to encompass the material world.' How humans relate to the spirit force is crucial to their well-being. The central focus of the religious exercises of human beings is therefore the harnessing of power inherent in the spirit force for their own advantage. To this extent, as Paul Gifford (2010: 13) argues, 'deities are consulted to ward off negative influences in important matters, [and] consultations are also [made] for lesser evils like failure to find a husband, infertility, giving birth to unhealthy offspring, and failure in business and education [and on the other hand], these spirits may be manipulated by others, particularly to inflict evil.'

Atiemo (2013: 21) postulates that 'since human beings themselves are believed to be part of this spiritual universe, they are not only credited with the capacity to communicate with it but are also regarded as, in a sense, vulnerable to the influences of spiritual forces, which are thought to wield effective power over the material world.' Max Assimeng (1989: 60) also recognizes the importance of the belief in spirits in the religious life in West Africa, as the 'concern to ward off evil spirits from human affairs.' He draws attention to the central importance of 'spirits' as a definitive category of religiousness in West Africa. Gifford (2010: 13) captures this succinctly:

[In Africa] All spirits have power which can affect humans. The physical realm and the realm of the spirit are not separate from each other. Nothing is purely matter. This world is one of action and counteraction of potent forces, spirit acting upon spirit. A stronger or higher being can easily destroy or impair the weaker or lower, and since humans are relatively low beings, they can be controlled by the former. A stronger or higher spirit acting negatively upon the spirit of any human may affect the whole family, clan or state. It therefore

${ }^{1}$ They include a Supreme Being (High God), whose power is believed to be manifested through a pantheon of gods. The conception of the spirit world includes lesser spirits which animate trees, animals, rocks, rivers, and other objects. 
becomes a central concern to avoid this or, where it is suspected to be imminent, ward it off quickly. The absence of such negative forces forms the idea of the good life.

Particularly, this idea of the cosmic struggle is strong in the Akan understanding of the nature of the universe. For one to be able to fulfil his or her aspirations in life requires the 'balance of power' in favour of the supplicant. This 'tilting of cosmic power' for one's own benefit or for the benefit of his or her community, is what Emmanuel Larbi referred to as maintaining the cosmological balance Larbi (n,.d.). In the view of Atiemo, it is this category of spirits as such that defines the religious point of view in West Africa (Atiemo 2013: 21).

For the purpose of this paper, I employ as working definition of religion, one put forward by Atiemo in his work Religion and Inculturation of Human Rights in Ghana. Emphasizing the incessant relationship and the influence from the world of spirits into the affairs of the material world, Atiemo defines religion as one that 'is concerned with the belief in, and presumed relationship with, spirit-beings who, though thought invisible, are yet believed to participate in the material world, over which they are thought to wield effective power and whose affairs they are believed to palpably affect' (Atiemo 2013: 21). This definition is adopted because it spells out a stipulative function of religion and thus, defines religion from the context in which this study is situated. Thus, in Ghana, the belief in spirit beings and the existence of the invisible world and their relationship with the material world is very explicit. Whilst other definitions such as the one put forward by Stephen Ellis and Gerrie ter Haar in their study of religion and politics in Africa is very important $^{2}$, they do not highlight the implicit nexus between the spirit-beings and their confluence with the material world, which is very important in the Ghanaian context. Again, this definition is adopted because 'in societies where the human world and the spirit world are generally thought to be interrelated, religion may become a dominant factor in establishing human rights, due to a belief that the rights held by human beings have their ultimate origin in the spirit world' (ter Haar 2011: 303).

${ }^{2}$ Ellis and ter Haar (2004:14f) define religion as 'a belief in the existence of an invisible world, distinct but not separate from the visible one, that is home to spiritual beings with effective powers over the material world'. 
Generally, religious beliefs produce corresponding religious' practices and religious behavior. The inter-relatedness of the religious system discussed in relation to the definitive category of the 'spirit' and people's thought and behavior towards their fellow human beings, and the desire to ward off evil has its basis in the traditional religiousness and/or system. This is because, the foundational religious practices in the traditional religions are one, "to establish links, relationship and close ties with the cosmic mysterious, mystical and spirit powers and forces'; two, to establish 'various spiritual and mystical communication with the spirit world and spirit beings' whether for good or for evil; and three, to also relate to the "various activities of the traditional African specialists' See Turaki (n.d.). Atiemo argues that 'postulated relationships between the world of spirits and the physical world imply communication between the two realms, and people's thoughts and behavior towards their fellow human beings are largely influenced by the ideals shaped by norms drawn from the context of these relationships' (Atiemo 2013: 22).

With inference from this background, there is no gainsaying in the fact that the traditional religious worldview of the African - particularly the belief in the invisible world which is 'full of spirits' and its interrelation to the material world has in consequence, influenced the development of certain corresponding religious practices of rituals such as those involving the killing of albinos who are regarded as persons who carry a rare sacred quality that makes them most preferred candidates for rituals. ter Haar has argued that 'religious believers are ultimately aware that successful living is dependent on their relationship with an invisible world, which they believe to be inhabited by spiritual forces that can make their presence felt in the visible world. Religious practice, therefore, consists to a large extent in a skillful manipulation of these unseen forces in order to manage the good and evil humans experience in their lives' (ter Haar 2000: 14). She notes that all societies have some notions of evil, and of the way in which human beings are implicated in such ideas are 'expressed through discourse of religion' (ter Haar 2000: 14).

In some African countries it is believed that 'albinos body parts could help politicians win elections and businessmen become fantastically rich overnight, and could cure infertility and ward off evil spirits' (Gifford 2015: 15). Gifford reports that the situation seems to be worse in Senegal where after the 2012 elections, in the legislative assembly, a deputy shouted across to the benches of the previous government; 'since you have lost power, albinos have 
found peace and we no longer find human remains in the streets'. In East Africa, albinism is a lucrative market business with a whole body part not costing less than $\$ 80,000$ (Gifford 2015: 15).

In Ghana, in both the run up to the 2008 and 2016 general elections, persons with albinism feared for their lives because of the belief that politicians use them for various rituals to enable them win power and hence, called for protection from the security agencies ${ }^{3}$. Myths persist that body parts of persons with albinism bring fortune and good health. Evidently, it is clear that ritual practices such as those involving the slaying of albinos and the discrimination against albinos in Ghana and elsewhere in Africa (especially East Africa) are informed and underlain by religious beliefs and their corresponding practices, behavior and feelings. It is an attempt to ward off evil and enjoy life free from perturbation.

The question is: how do religious beliefs and cultural values contribute to the plights of albinos in Ghana? What is the place of albinos within Ghanaian socio-religious space? And, how can the inculturation of human rights help mitigate the violence against albinos in Ghana?

In an enchanted space such as Africa, where people's worldviews, beliefs and practices are largely influenced by their religious beliefs and convictions, the stigmatization, discrimination, and myths surrounding albinism and their subsequent nuances against their rights may be very difficult to deal with. Nonetheless, if religion is the fulcrum through which these acts are legitimized, it can as well function as the substratum through which the religious and cultural beliefs of people can be addressed and harnessed in dealing with the situation. This is because most legal instruments that seek to deal with human rights issues tend to neglect the role played by religion in the implementation and translation of such rights in various cultures.

Methodologically, I will use inculturation as a framework in this study. In religious contexts, inculturation basically refers to the adaptation and/or the interface between religion and people's cosmologies and worldviews. Inculturation in this study is therefore defined as 'the process of encounter between the universal and the local that eventually results in the activation and redevelopment of local elements, which share some affinity with the universal ones, in such a way that both the local and the universal are mutually transformed. Applied to human rights, the resulting local version must overlap

${ }^{3}$ See Ghanaweb news item on Tuesday 31 May 2016. 
in meaning and practice with other local versions and harmonize with the global one' (Atiemo 2013: 51, 52). The argument here is that, before one can meaningfully address the issues of violence against albinos, there is the need to determine how people translate their religious beliefs and practices into their cultural life and experiences. It is also imperative to examine how external and internal factors also influence such decisions.

\section{Violence/Human Rights Abuses against Albinos in Ghana}

In June 2015, The Ghana Association of Persons with Albinism (GAPA) celebrated its first International Albinism Awareness Day in Accra with a public awareness rally and discussion forum. Those in attendance included some government officials, civil society organizations, media, hundreds of people with albinism from Ghana's ten regions and a former Member of Parliament. Some of the placards used during their historic trudge read: 'Send children with albinism to school'; 'Persons with albinism are human beings'; 'Albinism is not a curse' and; 'Say no to societal prejudice'4.

Albinism, which is an inherited condition from birth as a result of lack of pigment which usually changes the color of the skin, hair and eyes is usually greeted with resentment in most African communities (Murray 2015: 223 225). In many African communities, persons with Albinism often become fugitives by default not because of any fault of theirs but due to their condition. Notwithstanding the fact that albinism can be found in every part of the globe, Africa is estimated to have a high prevalence of Albinism with Tanzania alone recording about 200,000 albinos (Gifford 2015: 15). Ghana, for instance, is estimated to have a record number of albinos within the range of 1,800 and 5, $400^{5}$. In Ghana, Albinos are a visible minority and they are subjected to prejudice, stigmatization, discrimination and superstitions.

In many parts of the world, persons with albinism are largely seen as being incomplete. Virginia L. Small, in her paper 'Sociological Studies of People of Color with Albinism' writes:

Among the few papers being written specifically about the social and

\footnotetext{
${ }^{4}$ Report of the Maiden Edition of the International Albinism Awareness Day Celebration June 2015.

${ }^{5}$ A Report by Under the Same Sun on Albinism in Ghana (2015: 1).
} 
psychological status of people with albinism in dark-skinned families and communities was a study published in 1993 in the Dominican Republic. This study and others like it concluded that there was indeed a negative stigma attached to albinism as well as other "special populations". It states that in general, albinism is equated with, and categorized as a blemish, mark, stain, even disfigurement. That is, it is a visual stigma that makes society look at it with suspicion and fear. Unlike any other stigma albinism is the only condition of any type mistaken for mixed race. People with albinism are also perceived to be inscrutable, sinister, less capable or having a character flaw. In the study done the respondents stated that the community basically finds reasons to criticize and reject them. An earlier study was published in 1989 on people with albinism in Nigeria. As in the latter study this concluded that people with albinism may suffer socially and psychologically due to family and society's negative attitudes (Small in Thuku p.6).

A discernable characteristic of people with albinism is that a high number of them are 'legally blind' and very sensitive to light. While it is notable that most albinos can read large print and do not require Braille, they lack the capacity to see and read from a blackboard in a regular classroom. This limited vision often meets the criteria of a disability. In most cases, these structural barricades prevent them from participating fully in society on an equal basis with others ${ }^{6}$. For instance, besides battling with the physical inconveniences such as eye problems and skin cancer as a result of sun burns, persons with Albinism often face social and cultural challenges. In several communities, albinism is mostly associated with myths and delusion which makes their condition hardly (or not) accepted by other people. In a radio interview, an erstwhile board member of the Ghana Federation of the Disabled, Suleiman Adam, himself an albino, told Obaapa Radio that persons living with albinism are not welcome in most spheres of Ghanaian society. According to him, persons with Albinism encounter a lot of discrimination in the job market, marriage, education, health, religion, social life and inheritance ${ }^{7}$. In Ghana especially, educational

${ }^{6}$ A Report by Under the Same Sun on Albinism in Ghana (2015: 1).

${ }^{7}$ Today Ghana News. 30 October 2014. 
institutions do not provide them with the requisite resources and materials to enhance their education.

In most cases, albinos are given derogatory names by most ethnic groups in Ghana. They are constantly abused and ridiculed in the public with derogatory names and social tags that serve as a form of stigmatization. For instance, Ofri or ofridjato is an Ashanti term of derision for a person with albinism that means 'scorched or marked person.' In Anlo-Ewe, Gesoshi refers to the supernatural: an incomplete being, and Agbelimoryevu refers to plant. In Ewe, Gele so si refers to the supernatural and in Dagati, Gbangu also refers to the supernatural. Other terms of derision used of persons with albinism in Ghana include: cassava dough-white person, White person, White/red person, commanded from thunder and one conceived during mother's menstrual period $^{8}$.

In most communities or countries in sub-Saharan Africa, albinism is conventionally thought of as 'a curse' or as some form of 'punishment' from the gods or the ancestors for something wrong done by the parents. For centuries, children born with albinism have been routinely killed immediately after birth by parents, family members and mid-wives ${ }^{9}$. Myths about albinism continue to persist in many parts of Africa. Inadequate information on albinism has made it very difficult for parents, families and communities to explain very well the situation relating to their giving birth to a child with albinism (see Thuku p.2). It is reported that Peter Ash, the founder of Under the Same Sun (UTSS), a charitable organization working towards helping persons with albinism, is quoted in The Epoch Times as saying that:

The idea behind it is that albinos look different, particularly in Africa because it's not a Caucasian country, and 95 per cent of children with albinism are born to parents who are both black. You can imagine if you're black and all of a sudden you have a child who's whiter than most Caucasians and you have no idea that it's a genetic disorder (cited in Thuku , p. 3).

It is on record that Ghanaians with albinism have been attacked and murdered for ritual purposes but this happens less frequently compared to some other

${ }^{8}$ Under the Same Sun. 'Names Used for PWA'.

${ }^{9}$ See 'Africa Investigates: The Spell of Abino'. See also Thuku. 
African countries ${ }^{10}$. However, ongoing discrimination, stigma, marginalization and myths about persons with albinism create the preconditions for attacks. There is no doubt that Ghanaians with albinism live in fear of violence that has swept across other parts of Africa.

In Ghana, some communities and families consider it as a misfortune to give birth to Albinos and hence, attempts are made to either kill them at birth or banish them from the community. One of such communities in Ghana where albinos are not accepted is Atebubu in the Brong Ahafo Region. A clear case is when a first year student, Yussif Fatau, an albino, gained admission into the Atebubu Senior High School but was refused access to the boarding house because of his condition. As a result of this, his parents had to rent a house in the town to enable him attend the school. However, his landlord was approached by the traditional leaders of Atebubu that it was a taboo to have an albino in the town and that he should not allow the boy to stay in his house in order not to incur the wrath of the Traditional Authority. Upon further insistence on the right of the boy to education by the Albino Association of Ghana in the region, the Ankobeahene (a caretaker of the chief's palace) of Atebubu had this to say: 'But if they insist it is his fundamental human right to access education and reside anywhere, then it could happen that one day the parents would meet an empty room, without knowing who to ask or blame of the whereabouts of their son' (The Chronicle). In a similar incidence, Newton Kwamlia Katsekua, the Executive Director of the Ghana Association of Persons with Albinism attended a funeral at Akwamufie, in the Eastern Region of Ghana. During the funeral ceremony, four different parties warned him that local tradition does not tolerate people with albinism and hence, asked him to either hide or leave. According to him, he hid in a car for at least nine hours. Reporting the incident to several authorities did not yield any result since no action was taken by any of the authorities that received the claim ${ }^{11}$.

UTSS report that in 2014, Nana Agyare Osei Tutu III, Chief of Bukruwa, warned that people with albinism in his region were at risk of being killed for ritual purposes. This is because centuries-old tradition of the small town suggests sacrificing albinos to the gods of the town brings good omen to

${ }^{10}$ A Report by Under the Same Sun on Albinism in Ghana (2015: 2).

${ }^{11}$ An interview with Newton Kwamla Katseku, Executive Director of the Ghana Association of Persons with Albinism on June 6 and July 25, 2015. In A Report by Under the Same Sun on Albinism in Ghana (2015: 3). 


\section{Francis Benyah}

its indigenes. According to the report, the chief claimed he could not guarantee their safety and recommended they leave the area. According to the chief, the taboos against people with albinism were pernicious and he did not know how to stop them ${ }^{12}$. Again, UTSS reports that in 2009, a two-year-old boy with albinism was kidnapped. After a week, Akua Linda was spotted with the boy and apprehended at the Kejetia Bus Terminal in Kumasi. She confessed that she and an accomplice had conspired to sell his body parts ${ }^{13}$.

In another incident, Wahab, a thirty-three (33) year-old graduate teacher with albinism from Sapala in the Northern Region of Ghana also narrates his ordeal. As the first albino child to be born in his town and/or village, Wahab, was ostracized from his family and community, and survived three attempts of death on his life. This is what Wahab says about his predicaments: 'When I was born, people thought I was an evil child so they were just finding all ways and means to make sure they kill me when I was young'. According to Wahab, he was also referred to as 'Pig' in school: 'I was not able to see from afar, and whenever I moved closer to the board, they will be insulting me .... Some call me monkey, others also say I'm evil, some say I'm a small god, some even get to the extent of referring to me as a pig'. Recounting one of the attempted murders on his life in the Brong-Ahafo Region in Ghana, Wahab had this to say:

I saw a lot of people coming to the house. I heard them saying that we thank God, this year the harvest will be very plentiful, this year will have a lot of harvesting, anytime we have an albino to sacrifice to the gods, we get a lot of harvest that year. We thank God we have had one and this one is very energetic and very healthy... (Akoyam 2015).

There are also public rumors that albinos are mostly abducted by people who deal in money rituals, popularly known as Sakawa in Ghana for human sacrifices. The inhuman treatment, and disparaging and pejorative names and terms such as Ofridjato used of persons with albinism leads to discrimination based on color which is against the rights guaranteed in the Universal Declaration of Human Rights (UDHR) and all other major international and

${ }^{12}$ A Report by Under the Same Sun on Albinism in Ghana (2015: 3). See also, Koomson.

${ }^{13}$ A Report by Under the Same Sun on Albinism in Ghana (2015: 3). 
regional human rights instruments which variously state that no one shall be discriminated against on the basis of color, birth, health, or other status. It is important to say that even though in Ghana, there are laws that seeks to protect the right of individuals with disabilities such as persons with albinism, the level of enforcing such laws have not been encounraging. For almost about two decades now since Ghana ratified the International Covenant on Civil and Political Rights (ICCPR), for people with albinism in Ghana, these rights remain only a dream ${ }^{14}$. According to ICCPR, albinos have the right to life ${ }^{15}$, freedom from torture ${ }^{16}$ and security of the person ${ }^{17}$. They have the right to equality before the law and to its protection from discrimination ${ }^{18}$. However, the establishment of associations of persons with albinism in various regions of Ghana and subsequent report on discrimation towards persons with albinism by the media have helped in raising the level of awareness against discrimation towards albinos. Also, other international interventions by the United Nations especially on the creation of International day on people with albinism has brought about an appreciable level of campaign on the issue since, as indicated earlier, the albinism association in Ghana was able to organize it first international albinism awareness in the year 2015 with a rally in Accra. Such rallies, coupled with media campaigns, will help in raising awareness and thereby mitigate against such discriminations.

14 ICCPR Article 2, para 1. 'Each State Party to the present Covenant undertakes to respect and to ensure to all individuals within its territory and subject to its jurisdiction the rights recognized in the present Covenant, without distinction of any kind, such as race, colour, sex, language, religion, political or other opinion, national or social origin, property, birth or other status'.

${ }^{15}$ ICCPR Article 6, para 1. 'Everyone has the right to life ...'.

${ }^{16}$ ICCPR Article 7 'No one shall be subjected to torture or to cruel, inhuman or degrading punishment ...'.

${ }^{17}$ ICCPR Article 9 of the Covenant provides for 'the right of every person to security of person'.

${ }^{18}$ ICCPR Article 26 'All persons are equal before the law and are entitled without any discrimination to the equal protection of the law. In this respect, the law shall prohibit any discrimination and guarantee to all persons equal and effective protection against discrimination on any ground such as race, colour, sex, language, religion, political or other opinion, national or social origin, property, birth or other status'. 


\section{Are Albinos People like Us? Albinism vs. Human Rights}

Albinos are visibly different looking people because of the color of their skin and hair. It is evident that in most societies or communities where people or individuals in one way or the other are seen as different in appearance or viewed as 'people not like us', they are treated differently (Atiemo 2013:134). This explains why globally, minority groups are always in a vulnerable position (ter Haar 2000: 14). The fact is that their otherness which often becomes justifiable either through religious or secular ideology makes them susceptible to different treatment 'on the grounds that they are, after all, different' and hence, as ter Haar argues 'may be deemed to have fewer rights than people like us, or even no rights at all' (ter Haar 2000: 15). Other scholars including Kwame Anthony Appiah and Michael Ignatieff, have labelled this view the 'narcissism of minor difference' (Ignatieff 1997: 54; Appiah 1999). ter Haar (2000: 15) postulates that 'this clearly has major implications for human rights, which are claims that individuals are entitled to make simply by virtue of their status as human beings.' According to her 'it raises a question not so much about the nature of rights, as about the nature of humanity' (ter Haar 2000: 15). Thus, who the human being is and whether he or she has dignity and right. In her view, in any given culture or society, the answer to the question such as what people think constitutes a human being and who is therefore qualified to claim human rights, are, to be found in the belief system of the people. This is because 'in many cultures, people attach overwhelming importance to the spiritual dimension of a person, believing that it is this which defines him or her as possessing a truly human identity' and dignity (ter Haar 2011; ter Haar 2000: 16).

In other words, for us to gain a thorough understanding of our subject matter, there is the need to place into perspective an understanding of who a human being is, especially within our cultural context and delineate whether or not albinos are regarded as human beings who possess inherent human dignity and have rights. This is crucial because the answers to the popular notions of humanity, regarding what qualities the society or people suppose makes a person truly human and what precisely entitles a human being to make a claim to full humanity, differs relatively from one culture to the other. This, I think, will help us understand the reasons behind some of the unfortunate discrimination and violence meted and/or perpetuated against persons with albinism. I see this attempt as very important in our discussion because as noted 
earlier, the violence and discrimination meted out against persons with albinism are very largely underlain by the myth and misconception which surrounds their being as humans. Apart from the fact that the issue has in its nature, a religious concern, it is also a human rights issue since the acts perpetrated against them are violations of their human rights as enshrined in the Universal Declaration of Human Rights (UDHR) and International Covenant on Civil and Political Rights (ICCPR). As Atiemo points out, what makes discussion about human rights sometimes very cumbersome is the absence of a clear consensus on who the human being is, or what it means to be human. ter Haar's opinion on this lacuna is worth noting:

Scholarly debate on the Universal Declaration invariably turns upon the nature of these rights and ways of applying them, without questioning the notion of a human being. That is, in addressing the fundamental question of a human's rights and the application of these, the Declaration takes it for granted that we all agree upon what precisely is a human being (ter Haar 2000: 5).

Atiemo concurs that 'the basis of her argument is that the purely secular expression of human rights does not appear to be sufficiently meaningful to many cultures since the 'human being' - the central concern of human rights is conceived by most cultures in religious terms'. Thus, 'if we wish for a successful inculturation of human rights, we must give serious thought to the role played by religion.' (Atiemo 2013: 6; Molendijk 1999). This does not pertain to only African cultures but most places where human rights issues are embedded in cosmological views and beliefs. As ter Haar (2000: 3) argues, 'legal instruments are not enough if human rights are to be firmly grounded in different cultures, as people's understanding of human rights is informed by their own world views and cosmologies. It is plain that in many countries human rights ideology finds its theoretical justification in religion.' In most African societies, religion remains the point of reference for most fundamental issues. Lamin O. Sanneh (1990: 64) crisply enunciates the pervasive nature of religion within African public sphere in the following submission:

A basic and persistent trait of African societies is the importance of religion. It falls like a shaft of light across the entire spectrum of life, fused and undifferentiated at one end, and refracted and highly refined 
at the other. From casual, daily, and spontaneous contexts to somber highly structured public occasions, it is the focus of elaborate and detaild interest. In art and ritual, in speech, work and leisure, in field, home and travel, on land or on water, in health and in sickness, in need and in commitment, religion occurs with authoritative force. African communities have consequently lived, moved, and had their being in religion.

Religion forms an inseparable relationship with life in Africa and to take religion out of the African, is to take out the personality of his or her entire being.

Jack Donnelly (1985: 27) observes that the very term 'human rights' points to 'humanity, human nature, being, a person or human being' as their source. The problem, as he diagnoses, is 'to specify what 'human nature' means in this context and how they give rise to rights.' In the international human rights instrument, there is no real attempt to explain who the human being is. Yet the whole project of human rights is built on the conviction that all human beings have 'inherent dignity' ${ }^{19}$, 'dignity and worth' ${ }^{20}$, unique 'attributes of human beings' ${ }^{21}$, and that all human beings are bound together by a 'spirit of brotherhood' that makes them 'members of the human family' 22 . However, there has not been much effort to unpack these attributes that qualify the human being as a bearer of rights.

It is important to note that in both traditional and modern societies, different ideas of who is human and who is not, or at least, who is sufficiently human and who lacks that sufficiency have existed ${ }^{23}$. The existence of views

${ }^{19} \mathrm{Cf}$. Preamble to the Universal Declaration of Human Rights (UDHR) (1948); The common preamble to the International Covenant on Civil and Political Rights (ICCPR); and The International Covenant on Economic, Social and Cultural Rights (ICESCR) (1966).

20 The Vienna Declaration and Programme of Action (1993).

${ }^{21}$ African Charter on Human and People's Rights (1986).

${ }^{22}$ Article 1, UDHR.

${ }^{23}$ Kant for example does not accept that apart from white people other races have 'human dignity'. See for example van der Venn et al. (2004:270). See similar views of scholars such as Hegel, Montesquieu, Locke and Mill in other 
in several traditional communities that give rise to discrimination against children, women and the disabled as well as persons who look different [such as albinos] underscores the need to clarify as part of human rights discourses the issue of 'what precisely is a human being'. In combing through academic literature, there is no agreement as to what it is about human beings that gives them the 'inherent dignity' from which human rights arise.

Indeed, for most societies in the developing world, what constitutes human nature and what gives the human being special worth is supported by religious explanations. In contemporary Africa, ideas about the nature of the human being lean heavily towards the religious (Parrinder 1969; Wiredu 1996). The origin of human being is located in God, the Creator. It is God who created human beings and put divine essence in them. In addition, humans are spiritually connected to God before, during and after their lifetime in the African belief system. In African belief system, the origin of human beings could be discerned from the strong cord that links the African to the supersensible world which is reflected in the rich African spirituality (Parrinder 1969: 20). Different types of sayings in the African communities reflect the belief that God is the origin of human beings. For instance, the divine essence in human beings is designated with the same label as the name of God in some African communities. Humans are composed of visible and invisible elements both of which are necessary to have a whole human being (Parrinder 1969: 22). In Bantu-speaking parts of Africa, for example, the concept of 'human being' includes various categories of spirit beings and the human dead as well as living humans, while the category of 'thing' includes all the forces that do not act on their own but only through agency, under the command of a force with intelligence (ter Haar 2011: 304). In West Africa, various societies express the idea that a person consists of three different elements, which link the individual to the human world through both the maternal and paternal line of descent and to the world of spirits, considered to be the place of origin and final destination of humankind. This is illustrated by the Ghanaian philosopher Kwasi Wiredu in his discussion of the complexity of the word onipa, usually translated as 'human being' or 'person' (Wiredu 1996: 157 -160; see also Wiredu and Gyekye 1992). In the Akan language, a person (onipa) is in possession of three vital components (okra, sumsum and mogya) that link him or her to the visible

works such Davis (1966:403); Hengelbrock in van der Venn, et al. (2004:270). Parekh (1995:81-88). 
as well as the invisible world. The okra and sunsum constitutes the nonphysical aspects of the human being. The okra is translated 'soul' and the sunsum is translated 'spirit'. The third element which is the mogya is translated as 'blood'. This concept of human being has implications for kinship relationship. Kinship, primarily among the Akans and other ethnic group in Ghana is determined by blood. So these three constituents (okra, sumsum and mogya) represent the three spheres of life that are deemed vital for the survival of a human being: mother's family, father's family and the invisible world or the world of spirits. It is an individual's spirit that is believed to link the visible to the invisible world and to make a person truly human. The threefold composition of the human being carries with it ontological links with various metaphysical entities and social units. In the Akan concept, the human being is considered a child of God because it is God who is believed to give the okra (Wiredu 1996; Gyekye 1978).

Therefore, in contemporary Ghana, the conceptions of why the human being is sacred and worthy of dignified treatment are rooted in religious beliefs. In Ghana, for example, when people say the human being has dignity or worth or is sacred, they mean that the human being has been created by God and that there is something of the divine in every human being that links them with the world of spirits ${ }^{24}$. For example, southern Ghanaian societies such as the Akan, the $\mathrm{Ga}$ and the Ewe, in their traditional views of the human being, hold that the human being in essence is a composite being made up of material and immaterial components that link him/her to spiritual entities such as God, the deities and the ancestors. These entities constitute the highest possible realities that can be conceived and are therefore worthy of reverence. To link the essence of human beings to these is to endow them with a sacred value (Gyekye 1992: 114).

Now, an important question that confronts us is, are albinos regarded as human beings with inherent dignity and right? It is clear from the discussion so far that most cultures link the existence of humans as being the creation of God. However, what determines or what is used to ascertain whether or not each individual created by God has equal dignity is somewhat difficult since there is no fixed category. In his attempt to establish such a fact, Atiemo

${ }^{24}$ Not everybody expresses this in the same way, but all versions of the concept have in common the idea that every human being has worth because they are more than mere matter. 
employs the method of the performance of rites of passage and the treatment that are meted out to people at various stages in life such as birth and death. He employs this approach because the rites that are performed at these stages of life give some indication of the community's views and beliefs about the person with respect to their standing or status in the community and also determine how the society regards categories of human beings. For instance, whereas individuals without any deformity are treated well and buried nicely, people who look different such as cripples and hunchbacks are buried differently with the aim of sending signals to the spiritual world that such individuals are not needed in the community again. In some cases, children born with deformities are sometimes even killed. Twins and albinos are traditionally looked upon as carriers of special spiritual power ${ }^{25}$. But in contrast, whereas 'twins [are] traditionally almost always regarded as mascots bringing good luck when well handled, albinos and hunchbacks [are] regarded as persons who carried a rare sacred quality that made them the most preferred candidates for ritual involving human slaying' (Atiemo 2013: 135).

Despite these assumptions, however, it is important to note that traditional attitudes towards people who are physically- challenged or disabled and/or deformed such as the blind, cripple, hunchback etc. are generally, well treated (Atiemo 2013: 134, 135). However, the case of albinos is different. Albinos are ridiculed publicly with derogatory names as mentioned earlier, discriminated against in various public places and social life, and are also, subjected to inhuman treatment. The prejudice and ostracism of persons with albinism in various communities ostensibly dehumanizes them and relegate them as not human beings who belong to the natural world but a different world. To a very large extent, the treatment meted out against albinos indicate that they are less regarded as real human beings, or not humans at all and therefore, have no dignity, rights and place in the society. For instance, I have earlier indicated that in the Akan society, kinship relationship is determined by certain elements which include the okra, sumsum and mogya and this also, determines the traditional conception of human being in southern Ghana. Kinship, again, has implication for matters of succession and inheritance. The fact that persons with albinism are regarded as rare human beings and are denied certain inheritance due them, and are sometimes rejected by family

${ }^{25}$ See for example, the discussion of Atiemo (2013:134) on how people with disabilities are treated in Ghanaian societies. 
members due to their condition presuppose a denial of their kinship relationship by blood (mogya) and are therefore not seen as fully human to enjoy such privileges.

Again, from our discussion, it is obvious that society treats people who are considered 'not like us' differently. ter Haar (2000) argues that both religious and secular ideologies tend to impute evil notably to those who are not considered people 'like us'. According to her, 'both types of ideology have shown a capacity to destroy the lives of others by placing them outside the category of humans' (ter Haar 2000: 15). However, in her view, the way in which this happens may differ, but in all cases, it implies some form of disqualification as a person. In citing some concrete examples, ter Haar argues that in 1914, for example, the Carnegie Endowment for International Peace observed in relation to a war between Greece and Bulgaria that 'day after day the Bulgarians were represented in the Greek press as a race of monsters, and public feeling was roused to a pitch of chauvinism which made it inevitable that war, when it should come, should be ruthless...Deny that your enemies are men and you will treat them as vermin' (ter Haar 2000: 15). A similar incidence took place during the Second World War, when whole groups were described as not fully human, not 'people like us'. Anti-Arab pogroms in 1950s Algeria were known to French settlers as 'ratonnades' or 'rat-hunts'. Again, in preparation for the 1994 genocide in Rwanda, the organs of state and mass communication consistently conveyed the message that part of the population were actually 'cockroaches'. According to her, 'examples from all parts of the world indicate how effective and how lethal dehumanizing is as a mechanism of exclusion' (ter Haar 2000: 15). It is evident that in most African communities albinos are not considered 'people like us'. The issue of labelling people as 'not like us' always concerns matters of identity - who are we and who are they? 'It denies humanity to a person or a group. It is one extreme of the process of "othering", or the constitution of a primal opposition between "us" and "them", (ter Haar 2000: 15). This is clearly the situation that persons with albinism faces in Ghana and elsewhere in Africa.

\section{Inculturation of Human Rights as a Response to Discrimination and Violence against Albinos}

The theory and/or concept of 'inculturation' emerged in twentieth century Christian theology. The concept was first applied in the context of a mission 
field as a response for a general need to transmit the Christian faith - its theology, liturgy, and institutions - to a different local cultural and social contexts of the world. It is a modified form of 'enculturation', which in cultural anthropology implies the "process of acquiring the cultural traditions of a society' (Theodorson \&Theodorson 1996: 13; Onwubiko 1992: 8). However, in the context of human rights discourses, 'one wonders whether the concept "contextualization" instead of "inculturation" would not have been more appropriate' (Atiemo 2013: 50; see also Pobee 1992: 39; Marty 1993). According to Atiemo, this question is raised in the light of often repeated distinction drawn between the two: that whereas 'contextualization' and 'liberation' deal with issues of politics and social justice, 'inculturation' deals only with issues of culture narrowly defined as involving such elements as 'language, symbols, and rites' (Atiemo 2013: 50: see also, Martey 1993). This concurs with the highly influential definition of culture by Clifford Geertz (1973: 89), which emphasizes the transmission of 'meanings embodied in symbols' or 'inherited conceptions expressed in symbolic forms'. It also harmonizes with the 2001 Universal Declaration on Cultural Diversity (UDCD) of UNESCO. The UDCD states, 'culture should be regarded as the set of distinctive spiritual, material, intellectual and emotional features of society or a social group, and that it encompasses, in addition to art and literature, lifestyle, ways of living together, value systems, traditions and beliefs.' Conscious of the propensity to misinterpret culture and abuse it, the Declaration provides in Article 4 that 'no one may invoke cultural diversity to infringe upon human rights guaranteed by international law'.

The inculturation of human rights results from a long process of encounter of the universal culture with the local at the deepest level. The danger to any process of inculturation is to engage a culture at the superficial level, dwelling on the explicit, to the neglect of the deeper underlying invisible dimension. Inculturation engages culture at all levels but, especially, at the deep level of meaning. In Ghana, the themes that come up strongly and stands up as very significant in the project of the inculturation of human right are located and construed within the context of a basic spiritual worldview which include; the conception of human being; what is meant by human dignity; the place of the individual in the community; relations between rulers and the ruled; mutual rights and obligations between individuals.

The process of the inculturation of human rights, as a framework used in this work, involves four elements: 'spontaneous or popular dialogue', 
'translation', 'confrontation', and 'directional or formal dialogue' (Atiemo 2013: 55-58). These four analytical elements are not to be interpreted in terms of either distinct or 'unconnected phases or sequential stages of a process' but, 'are to be understood in terms of overlapping elements that may be present at the same time at various stages in the complex and dynamic process of social change' (Atiemo 2013: 55). As P. Arrupe (1978: 4) argues, 'Inculturation includes various and diverse levels which must be distinguished but which cannot be separated'. Thus, inculturation must, of necessity, involve comparison - a comparison of the global culture with the local.

The first element in this model of the inculturation of human rights, spontaneous or popular dialogue, deals with the initial or the primary stage of the inculturation process. Very significantly, this step of the process of inculturation begins 'as a practical process of transformation by engaging concrete situations at the popular level, independent of, and outside the awareness of, the formal or official sectors of the society' (Atiemo 2013: 55). The second element which is the translation basically 'refers to the engagement between human rights and the local culture at the deep level of meaning so that the local expressions will spring out of the inner worlds of the local culture in a natural, effortless way' (Atiemo 2013: 57; see also, Sanneh 2003: 16-18; Silva 2003; Clarke 1982: 123; Twum-Barima 1985). The third element which is the confrontation refers 'to the situation whereby seemingly diverse and incompatible elements clash. It involves contestations, negotiations, rejections and compromises. It leads to the clarification, reconceptualization and rearrangement of aspects of the local culture that imply a contradiction with the values, which the universal system sets out to protect and promote'. Finally, the fourth element which is the Directional or formal dialogue refers 'to formal interventions aimed at clarifying ambiguous aspects of the inculturated version' (Atiemo 2013: 58).

As indicated earlier, largely, the discrimination and violence against albinos in Africa is entrenched in cultural as well as religious beliefs and practices. As a result of this, the inculturation approach in my own opinion offers one of the best frameworks in addressing the issue. This is because beliefs generate attitudes and these attitudes become entrenched in society and influence people's way of doing things and since some of these beliefs have been handed down or passed on through generations, there are no questions regarding them or only few people attempt to question its place in the society. Even in situations where the educated people in the society questions them, 
they still have at the back of their minds or somewhere in their consciousness some of the influence, the fear, the biases, and the prejudices - though they may not talk about them openly. So in this sense, what the inculturation framework seeks to do, is to look up for the stages where societies are, with respect to these attitudes, beliefs, practices and sometimes responds or reacts to supposed ritual kind of dirtiness, and the polluting effect or the bad luck carrying effect of being disabled or people with disabilities. An example is people who look different such as albinos.

The first attempt in responding to the issue is to engage in spontaneous or popular dialogue. This will involve the exposure of people to new ideas about the condition through different platforms such as the media (radio and television) and other forums. For example, there can be an albinism awareness on TV and radio spots, seminars, and 'in-person' encounters to raise awareness about the condition and its stigma and to humanize and normalize albinism. At this initial stage, individuals begin to learn new things either from colleagues or from friends, through reading and the ones they hear from the media. As these new ideas or information come into the public domain, the public or the people consciously or unconsciously engage themselves in an unconscious and spontaneous kind of dialogue or debate which makes them aware of the situation or the condition and the necessary attention or care it deserves. This is usually independent and outside any kind of official or formal sectors of the society.

The second level of the inculturation process is translation, which involves the engagement of beliefs of the people and the values underlying them. This stage usually overlaps with the third element which is confrontation. Confrontation becomes very relevant at this stage in the sense that in an attempt to engage people, there will be the need to educate them about their belief systems and their underlying assumptions and delinquencies. Not only through education but also, the act of persuasion and interventional approaches are very relevant at this stage. Thus, there will be a need to persuade people and intervene in different ways to curb the situation. Very important at this stage can be the use of institutions or key stakeholders such as the church, family, NGOs and educational institutions to consciously educate people. For ex-ample, family members, legal guardians, caregivers, youth, schools, communi-ties, community leaders, the media and other civil society organizations can be targeted by policy makers with the aim of demythologizing messages about human dignity and respect, focusing on simple 
genetic and medical explana-tions, offering easy ways to live with and care for the condition of albinism. This is very important because more often than not, in Ghana, discrimination against persons with albinism is often reinforced through popular culture (e.g, music, arts, internet, films, television, radio etc.). It is important for government and civil society organizations to challenge negative stereotypes about albinism in popular culture and film, which reinforce discrimination and empower bullies. Groups and individuals such as academics, journalists, film producers, film directors, writers, online content creators and popular culture curators can be educated and encouraged to abandon pernicious negative portrayals of people with albinism in favour of portrayals as neutral or positive characters, in roles unrelated to the condition ${ }^{26}$. At the level of confrontation also comes in the act of legislation. This act of legislation is meant for policy makers such as the government to teach or educate people to be conscious of the laws that are in existence against such acts. Through these legislation and education, many people would consciously come to the level where at least they would be aware of the wrongness of their old attitude influenced by their cultural presuppositions or belief systems and worldviews.

At this point, resort to directional dialogue becomes very relevant and necessary to clarify any ambiguous aspects of the inculturated version. It specifically aims at explaining issues that was not well understood or misapplied during the process of the inculturation. During this stage, governments could utilize public education mechanisms and infrastructure already in use for public campaigns. However, this would still not leave out the other elements. As stated earlier, the elements in the inculturation approach are not to be understood in terms of either 'unconnected phases or sequential stages of a process' but as overlapping elements during the process of social change. Hence, the problem with this approach is that if you want to deal with it according to stages or phases, then it becomes problematic. But if you deal with them as overlapping principles then it can hitherto be applied at the same time at different stages. This is because, sometimes depending upon the nature of the society where, as a result of education, a particular class may already have gone to the level where a kind of a directional approach should be sufficient without causing any disorientation, other groups may not be well

${ }^{26}$ See, for example, A Report by Under the Sun Same on Albinism in Ghana (2015: 4). 
educated and still be raising questions that may have to be handled with the principle of translation.

For instance, in our context as Africans and more particularly as Ghanaians, translation might be the best approach to solve issues relating to violence against albinos. But we cannot end there because translation would involve education and the creation of awareness leading to understanding of the issue. However, apart from that, confrontation and directional approaches still become necessary in the sense that even though people who normally go through the inculturation process may comply with human rights provisions, there will always be a conservative minority who may have to be confronted legally in order to oust out their primitive ideologies, and this happens only when prosecution and punishment are exerted. The argument here is that, when you don't get it straight away to want to begin to prosecute and punish, after some time, through the processes of inculturation, you would get to the confrontational level and still realize that there are elements of conservatism and stubbornness because probably the custodians' benefits in a way. In that sense, the exclusion of the confrontation element might not help achieve the goals. However, at this stage, majority of the people would have come into compromise and therefore, support the punishment of offenders.

It is important to emphasize that the translation approach is more conducive for our context than the traditional and the advertorial, strict legal and individualistic approach to human rights issues in other societies like we find in the western context. It is important to admit that if you make a go at human rights through legislation, through the radical individualistic conventional approaches of the west, it may be more revolutionary. However, these approaches may not be feasible or well suited for our context particularly as Africans because in looking at the nature of our societies, approaches that turn towards addressing issues of communal sensitivity are better approaches than litigational or confrontational ones. As Sally Merry (2006: 5) argues, one of the several conundrums in applying human rights to local situations is that 'human rights ideas are more readily adopted if they are packaged in familiar terms, but they are more transformative if they challenge existing assumptions about power and relationships'.

\section{Conclusion}

In sum, this paper has demonstrated that the discrimination and violence 
against albinos in Africa particularly Ghana is entrenched in cultural as well as religious beliefs and practices. The paper has also highlighted that it is also, a human rights issue since the situation undermines the personal worth and dignity of the individual. The culture as well as the religious issues that undergird the violence acts is very crucial because primarily, the basic constituent of any culture is the human person. It is the cultural memory that determines the sub-consciousness of the individual. It is thus the cultural value system in solidarity with other value systems that helps determine the relationship of people within or outside their cultures. The cultural memory enfolds and permits people to promote the rights of humans or not. So, the notion and/or the nature of the human, as expressed by different cultural groups cannot be expunged in any human rights discourses that seek to protect the rights of the humans within specific cultures. Thus, for any human rights laws to be enforced properly, how people translate their religious beliefs (inculturation) in the interpretation of human rights cannot be taken for granted. This is especially important for Africans because even though we are in a secular and post-modern world, Africans are largely, transcendentally orientated. The omission of a clear definition of the human being in human rights discourses has been lamented by Gerrie ter Haar, who in support of Vaclav Havel calls for a consideration of the 'spiritual dimension and spiritual origins of the values guarded by the United Nations' and their translation into the organization's practical activities (Atiemo 2013; Wulf 1999: 208). In Ghana, for example, 'the religious factor has always exerted considerable influence on process of social transformation because the culture is largely religious' (Atiemo 2013: 4). This convergence of value system with custom and religion makes exclusion and marginalization of persons with albinism and or any minority groups economically disadvantaged throughout Africa. This makes the plight of Albinos in Ghana and elsewhere in Africa a serious concern.

\section{References}

African Charter on Human and People's Rights 1986. Available at: http:// www.achpr.org/instruments/achpr/. (Accessed on 15 December 2016.)

'Africa Investigates: The Spell of Abino'. A video documentay on the plight of Albinos in Tanzania by the award winning Ace Journalist Anas Aremeyaw Anas into the witchcraft driven albino body parts trade in 
Tanzania. Available at: https://www.youtube.com/watch?v=BVAyFlV w_e8. (Accessed on 12 December, 2016.)

Akoyam, F. Unwanted: How Albinos are Killed for Rituals in Ghana. JoyNews

01 May 2015. Available at: http://www.myjoyonline.com/news/2015/

May-1st/unwanted-how-albinos-are-killed-for-rituals-in-ghana.php.

(Accessed on 10 December 2016.)

An interview with Newton Kwamla Katseku, Execituve Director of the Ghana Association of Persons with Albinism on 6 June and 25 July 2015. In A

Report by Under the Same Sun on Albinism in Ghana 2015. The Civil and Political Rights of Ghanaians with Albinism.

A Report by Under the Same Sun on Albinism in Ghana 2015. The Civil and Political Rights of Ghanaians with Albinism.

Appiah, K.A. 1999. Interview: Commenting on his Essay 'Color Conscious:

The Political Morality of Race'. de Volkskrant 23 October.

Assimeng, M. 1989. Religion and Social Change in West Africa. Accra: Ghana University Press.

Atiemo, A.O. 2013. Religion and the Inculturation of Human Rights in Ghana.

London: Bloomsbury.

Clark, P.B. 1982. West Africa and Islam: A Study of Religious Development from the $8^{\text {th }}$ Century to the $20^{\text {th }}$ Century. London: Edward Arnold Ltd.

Common Preamble to the International Covenant on Civil and Political Rights (ICCPR). Available at: http://www.ohchr.org/en/professionalinterest/ pages/ccpr.aspx. (Accessed on 15 December 2016.)

Davis, D.B. 1966. The Problem of Slavery in Western Culture. Ithaca, NY: Cornel University Press.

Donnelly, J. 1985. The Concept of Human Rights. London/Sydney: Croom Helm.

Ellis, S. \& G. ter Haar. 2004. Worlds of Power: Religious Thought and Political Practice in Africa. London: Hurst \& Company.

Geertz, C. 1973. The Interpretation of Cultures: Selected Essays. New York: Basic Books.

Ghana Association of Persons with Albinism 2015. Report of the Maiden Edition of the International Albinism Awareness Day Celebration. 'Persons with Albinism Worthy of Respect and Dignity'. June.

Ghanaweb news item on Tuesday 31 May 2016. Sacrificing Albinos for Political Power 'Sad' - Delle. Available at: http://www.ghanaweb.com/ GhanaHomePage/NewsArchive/Sacrificing-albinos-for-political-power- 
sad.-Delle-443520. (Accessed on 15 January 2017.)

Gifford, P. 2015. Christianity, Development and Modernity in Africa. London: Hurst and Company.

Gyekye, K. 1992. Person and Community in African Thought. In Wiredu, K.

\& K. Gyekye (eds.): Person and Community. Washington, DC: The

Council for Research in Values and Philosophy.

Gyekye, K. 1995. African Philosophical Thought: The Akan Conceptual Scheme. Revised Edition. Philadelphia: Temple University Press.

Gyekye, K. 1978. The Akan Concept of a Person. International Philosophical Quarterly 18,3: 277-287.

Hengelbrock, J. The Stranger between Oppression and Superiority: Close

Encounter with Heinz Kimmerle. Homepage IFK-International

Communication, cited in van der Venn, et al. (2004).

Ignatieff, M. 1997. The Warrior's Honor: Ethnic War and the Modern Conscience. New York: Henry Holt \& Co.

International Covenant on Civil and Political Rights (ICCPR). Available at: http://www.ohchr.org/en/professionalinterest/pages/ccpr.aspx. (Accessed on 15 December 2016.)

Koomson, F. Albino Killing Craze Stares at Ghana Modern Ghana. Available at: https://www.modern ghana.com/news/207231/1/albino-killing-crazestares-at-ghana.html. (Accessed on 11 December 2016.)

Kalu, O.U. 2010. Continuity in Change: Pentecostalism in African Map of the Universe. In Kalu, W.J. N. Wariboko \& T. Falola (eds.): Christian Missions in Africa: Success, Ferment and Trauma. Asmara: African World Press.

Larbi, E.K. n.d. The Nature of Continuity and Discontinuity of Ghanaian Pentecostal Concept of Salvation in African Cosmology. Cyber Journal for Pentecostal-Charismatic Research. Available at: http://www. pctii.org/cyberj/ cyberj10/larbi.html. p. 3. (Accessed on 16th June, 2016.) Martey, E. 1993. African Theology: Inculturation and Liberation. Maryknoll, NY: Orbis Books.

Meyer, B. 1999. Translating the Devil: Religion and Modernity among the Ewe in Ghana. Edinburgh: Edinburgh University Press.

Merry, S.E. 2006. Human Rights and Gender Violence: Translating Law into Local Justice. Chicago: University of Chicago Press.

Molendijk, A.L. 1999. In Defence of Pragmatism. In Platvoet, J.G. \& A.L. Molendijk (eds): The Pragmatics of Defining Religion: Contexts, Con- 
cepts and Contest. Leiden/Boston: Brill.

Murray, B.H. 2015. Albinism in Africa: A Medical and Social Emergency. International Health 7: 223-225.

Onwubiko, O.A. 1992. Theory and Practice of Inculturation: African Perspective. Enugu: Snaap Press.

Pobee, J.S. 1992. Skenosis: The Christian Faith in an African Context. Gweru: Mambo Press.

Parekh, B. 1995. Liberalism and Colonialism: A Critique of Locke and Mill.

In Pieterse, J.N. \& B. Parekh (eds.). Decolonization of Imagination:

Knowledge and Power. London: Zed Books.

Parrinder, G. 1969. West African Religion: A Study of the Beliefs and Practices of Akan, Ewe, Yoruba, Ibo, and Kindred Peoples. London: Epworth Press. Preamble to the Universal Declaration of Human Rights (UDHR) 1948.

Available at: http://www.un.org/en/universal-declaration-human-rights/.

(Accessed on 15 December 2016.)

Sanneh, L. 1990. New and Old in Africa's Religious Heritage: Islam, Christianity and the African Encounter. In Walls, A.F. \& W.R. Shenk (eds.): Exploring New Religious Movements: Essays in Honor of Harold W. Turner. Indiana: Mission Focus.

Sanneh, L. 2003. Whose Religion is Christianity? The Gospel beyond the West. Grand Rapids \& Cambridge: W.B. Eerdmans.

Silva, D.J. 2003. Western Attitudes toward the Korean Language: An Overview of Late Nineteenth and Early Tweentieth-Century Mission Literature. Korean Studies 26,2: 270-286.

Small, V.L. 1998. Sociological Studies of People of Color with Albinism. In Thuku, T. Myths, Discrimination, and the Call for Special Rights for Persons with Albinism in Sub-Saharan Africa. Available at: www.underthesamesun.com/sites/default/files/MYTHS.Final_.pdf.

(Accessed on $12^{\mathrm{h}}$ January 2017.)

ter Haar, G. 2000. Rats, Cockroaches and People like Us: Views on Humanity and Human Rights. The Hague: Institute of Social Studies.

ter Haar, G. 2011. Religion and Human Rights: Searching for Common Ground. In ter Haar, G. (ed): Religion and Development: Ways of Transforming the World. London: Hurst and Company.

The Chronicle. Available at: http://thechronicle.com.gh/albinos-banish-fromatebubu/. (Accessed on 30 April 2016.)

The International Covenant on Economic, Social and Cultural Rights. 
(ICESCR) 1966. Available at: http://www.ohchr.org/EN/Professional Interest/Pages/CESCR.aspx. (Accessed on 15 December 2016.)

The Vienna Declaration and Programme of Action 1993. Available at: http://www.un.org/en/events/humanrightsday/2003/vienna.html.

(Accessed on 15 December 2016.)

Theodorson, G.A. \& A.G. Theodorson 1996. Modern Dictionary of Sociology.

New York: T.Y Cromwell.

Thuku, T. Myths, Discrimination, and the Call for Special Rights for Persons

with Albinism in Sub-Saharan Africa. Available at:

www.underthesamesun.com/sites/default/files/MYTHS.Final_.pdf.

(Accessed on $12^{\mathrm{h}}$ January 2017.)

Today Ghana News 2014. Albinos in Ghana Face Extinction. 30 October. Available at: http://todayghananews.com/2014/10/30/albinos-ghana-face -extinction/. (Accessed on 10 December 2016.)

Turaki, Y. African Traditional Religious Systems as Basis of Understanding

Christian Spiritual Warfare. Lausanne Movement. Available at: https://www. lausanne.org/content/west-african-case-study. (Accessed on 6 June 2016.)

Twum-Barima, K. 1985. The Cultural Basis of Our National Development. Accra: Ghana Academy of Arts and Sciences.

Under the Same Sun. 'Names Used for PWA'. Available at: http://www.under thesamesun.com/node/492. (Accessed on 10 December 2016.)

van der Ven et al. 2004. Is There a God of Human Rights? The Complex Relationship between Human Rights and Religion: A South African Case. Leiden \& Boston: Brill.

Wiredu, K. 1996. Cultural Universals and Particulars: An African Perspective. Bloomington, IN: Indiana University Press.

Wiredu, K. \& K. Gyekye 1992. Person and Community: Ghanaian Philosophical Studies. Washington, D.C.: Council for Research in Values and Philosophy.

Wulff, D. 1999. Psychologists Define Religion. In Platvoet, J.G. \& A.L. Molendijk (eds.): The Pragmatics of Defining Religion: Contexts, Concepts and Contest. Leiden/Boston: Brill.

Francis Benyah University of Ghana Legon fbenyah87@gmail.com 